\title{
STUDIES ON THE ROOTING OF OLIVE CUTTINGS
}

\author{
El- Ghayaty, S. H.* ; M. A. El- Serafy * ; E. S. Hegazy ${ }^{* *}$ and A. E. \\ Abd El-Monim *** \\ * Hort. Dept., Fac. Agric., AL-Azhar University \\ ** Fruit Dept., Fac. Agric., Cairo University \\ ${ }^{\star * \star A}$ Agric. Res. Center, El Giza - Egypt

\section{ABSTRACT}

This study was conducted in orchard and greenhouse of the developing agricultural systems project, Faculty of Agriculture, Cairo University, in the period from 2006 to 2008 in order to improve the ability of rooting in Kalamata olive cv. twenty two years old Kalamata olive cv. trees were used as mother plants. One year old branches were used to prepare the cuttings in four dates (Middle of November, first of December, Middle of December, and first of January). Mechanical treatments (wounding) alone and with some growth regulator treatments were used to stimulate rooting ability. The study revealed that the best rooting for Kalamata cuttings were obtained when cuttings were prepared in the middle of November with two leaves and treated by wounding and beating the basal portion after dipping bases of cuttings in indole butyric acid solution (IBA) at $4500 \mathrm{ppm}$. Microscopical of the transverse sections showed that there were no clear differences between dates of preparing cuttings in sclerenchyma cells volume and count.

\section{INTRODUCTION}

The olive tree (Olea europaea L.) is considered as an important crop in arid land. The different species showed great variation in the rooting potential of their cuttings due to clonal variation. Wide variations in rooting ability of leafy cuttings were found among olive cultivars (El-Nabawy et al., 1983; Salama et al., 1987; Fouad et al., 1989 and El.Said et al., 1990). There are many problems in olive propagation including rooting difficulty of cuttings due to lack of auxin and other factors such as anatomical structure and the presence of continuous sheath of sclerenchyma forming mechanical barrier to the emergence of the newly formed rootlets (Emtithal et al., 1995). However the mentioned relationship between the density or continuity of the sclerenchyma ring and the ease of rooting was not observed by Sachs et al. (1964) in the case of olive, pear and cherries cuttings.

This study was carried out to investigate the effect of some mechanical treatments (wounding) alone or with some growth regulator treatments (IBA and $\alpha$ - Naphthol at different concentrations) at different dates (Middle of November, first of December, Middle of December, and first of January) on developing the rooting ability of this cultivar (Kalamata). The origin of adventitious roots in this concern was also anatomically examined in order to investigate if there are clear differences between dates of preparing cuttings in sclerenchyma cells volume and count.

\section{MATERIALS AND METHODS}

This research was conducted in orchard and greenhouse of the developing agricultural systems project (former project California), Faculty of 
Agriculture, Cairo University, in the period from 2006 to 2008. Twenty two years old Kalamata olive cv. trees were used as mother plants to prepare the studied cuttings. The young branches of one year old were cut into the $15-$ $20 \mathrm{~cm}$-long with 2 full expanded leaves retained at the discaled end with $2-4$ buds to prepare the studied cuttings. The cuttings were cultivated in plastic boxes containing mixture of peatmoss and sand 1: $4 \mathrm{v} / \mathrm{v}$ with size $(60 \times 40 \times$ $15 \mathrm{~cm}$ ). Irrigation system under intermittent mist was applied for $10 \mathrm{sec}$. puls and pause every 5 minutes intervals during day light hours under greenhouses seran (a net with black color used for shading) with shading of $75 \%$. The irrigation system was applied for a period of two months; the plastic house was covered with transparent plastic in the winter without irrigation. Adaptation process was applied by the transfer of plastic box out of greenhouse and putting them outdoor sandy layer and natural irrigation once a day for 7 - 10 days. Then after adaptation outdoor successful cuttings were counted. Planting of the cuttings was carried out in four dates (middle November, first December, middle December, and first January). The Experiment included the use of mechanical treatments alone (wounding on the basal portion (about one inch) by making $3: 5$ incisions), or with the addition of some growth regulator (indole butyric acid solution (IBA) and $\alpha$ Naphthol ( $\alpha$ - Naph.) at some different concentrations. The experiment included a number of treatments described below. Every treatment had three replicates and each replicate contains 10 cuttings as follows:

1- Control (without any treatments).

2- Wounding on the basal portion (about one inch) by making 3: 5 incisions.

3 - Wounding on the basal portion (about one inch) by making 3: 5 incisions and then dipping the bases of cuttings in indole butyric acid solution (IBA) at $((3500,4000$, and $4500 \mathrm{ppm}))$ for 10 seconds.

4- Wounding on the basal portion (about one inch) by making $3: 5$ incisions and then dipping the bases of cuttings in $\alpha$ - Naphthol solution ( $\alpha$ - Naph.) at $(5,10$, and $15 \mathrm{ppm})$ for 10 seconds. The cuttings were directly planted after the previous treatments for a period of 8-10 weeks, according to the different planting dates (middle November, first December, middle December, and first January). The following measurements were taken on cuttings:

$1-$ Rooted cuttings $=$ Number of the cutting that formed roots $\times 100$

Total number of treated cutting

2- Average number of roots per cutting $=\begin{gathered}\text { Total number of roots for successful cuttings } \\ \text { Number of cuttings }\end{gathered}$

3- Average length of roots in the successful cuttin = Total length of roots for successful cuttings Number of cuttings

Anatomical Studies:

Stem leafy cuttings of Kalmata, were prepared in early four dates (middle November, first December, middle December, and first January) during both 2006 and 2008 seasons, treated with IBA and planted under mist 
as described before. Samples from the basal portion of the stem cuttings were taken at two weekly intervals during the rooting period. These were killed and stored in F.A.A. (Formalin-Aceto-Alcohol) solution until sectioning. For softening, samples were washed and stored for 2 days in tap water. Transverse sections were made by sledge microtome, 25 micrones thick, stained with safranin followed by fast green, then dehydrated, cleared in xylol and mounted in Canada balsam for microscopical examination and photography (Johansen, 1940).

Statistical analysis:

A factorial analysis in randomized complete block design with three replications was used. The dates were randomly assigned in the main plots, rooting treatments (control, wounding, IBA and $\alpha$ - Naphthol) were randomly distributed in sub plots. The treatment means were compared using L D S test according to Steel and Horrie (1960).

\section{RESULTS AND DISCUSSION}

Effect of wounding alone or wounding with different concentrations from (IBA and $\alpha$-Naphthol) at different preparation of cuttings dates on: 1- Average percentage of rooted cuttings:

Results in Table 1 showed that the highest significant average of rooted cuttings percentage were found at the treatments of IBA $(3500 \mathrm{ppm})+$ cuttings wounding, IBA (4500 ppm) + cuttings wounding and IBA (4000 ppm) + cuttings wounding respectively in comparison with the other treatments in both seasons while the lowest significant were found at the treatment of wounding and beating alone.

The other treatments showed that the hormone at different concentrations (IBA) + cuttings wounding was high significant average percentage of rooted cuttings compared with the hormone at different concentrations ( $\alpha$-Naphthol) + cuttings of wounding.

Concerning the effect of different date treatments, the results showed that middle November date gave the highest significant effect after dipping in IBA at 3500 ppm + cuttings wounding in comparison with other dates in the two seasons. On the other hand, the lowest significant effect resulted from first January date.

It can be concluded that, the treatment IBA at 3500 ppm + cuttings wounding at middle November is the best treatment for rooting as it averaged between $23.33 \%$ and $16.66 \%$ in both seasons respectively.

On contrast (El-Said, 1986) found that treatment IBA at (4000 ppm) + cuttings wounding was the highest of average percentage of roots compared with IBA treatment alone. 
Table 1: Effect of wounding alone or wounding with different concentrations from (IBA and $\alpha$-Naphthol) at different preparation of cuttings dates on the average percentage of rooted cuttings during 2006 and 2007 seasons

\begin{tabular}{|c|c|c|c|c|c|}
\hline \multicolumn{6}{|c|}{ Average percentage of rooted cuttings (\%) } \\
\hline \multicolumn{6}{|c|}{ Season 2006} \\
\hline Treatment & $\begin{array}{c}\text { Middle } \\
\text { Nov. }\end{array}$ & $\begin{array}{l}\text { First } \\
\text { Dec. }\end{array}$ & $\begin{array}{c}\text { Middle } \\
\text { Dec. }\end{array}$ & $\begin{array}{c}\text { First } \\
\text { Jan. }\end{array}$ & Mean \\
\hline Control & 3.33 & 0 & 0 & 0 & 0.83 \\
\hline Cuttings Wounding & 0 & 0 & 0 & 0 & 0 \\
\hline IBA (3500 ppm) + Cuttings Wounding & 23.33 & 0 & 6.66 & 0 & 7.49 \\
\hline IBA (4000 ppm) + Cuttings Wounding & 13.33 & 0 & 0 & 0 & 3.33 \\
\hline IBA (4500 ppm) + Cuttings Wounding & 20.00 & 0 & 6.66 & 0 & 6.67 \\
\hline a-Nph.5 ppm + Cuttings Wounding & 3.33 & 0 & 0 & 0 & 0.83 \\
\hline$\alpha-N p h .10$ ppm + Cuttings Wounding & 0 & 6.66 & 0 & 0 & 1.67 \\
\hline a-Nph.15 ppm + Cuttings Wounding & 3.33 & 0 & 0 & 0 & 0.83 \\
\hline Mean & 8.33 & 0.83 & 1.67 & 0 & \\
\hline \multicolumn{6}{|l|}{ LSD at 0.05} \\
\hline Date & \multicolumn{5}{|c|}{0.0002} \\
\hline Treatments & \multicolumn{5}{|c|}{0.0003} \\
\hline Date $\times$ Treatments & \multicolumn{5}{|c|}{0.0005} \\
\hline \multicolumn{6}{|c|}{ Average percentage of rooted cuttings (\%) } \\
\hline \multicolumn{6}{|c|}{ Season 2007} \\
\hline Treatment & $\begin{array}{c}\text { Middle } \\
\text { Nov. }\end{array}$ & $\begin{array}{l}\text { First } \\
\text { Dec. }\end{array}$ & $\begin{array}{c}\text { Middle } \\
\text { ]Dec. }\end{array}$ & $\begin{array}{l}\text { First } \\
\text { Jan. }\end{array}$ & Mean \\
\hline Control & 0 & 0 & 0 & 0 & 0 \\
\hline Cuttings Wounding & 0 & 0 & 0 & 0 & 0 \\
\hline IBA (3500 ppm) + Cuttings Wounding & 16.66 & 0 & 3.33 & 0 & 4.99 \\
\hline IBA (4000 ppm) + Cuttings Wounding & 10.00 & 0 & 0 & 0 & 2.50 \\
\hline IBA (4500 ppm) + Cuttings Wounding & 13.33 & 0 & 3.33 & 0 & 4,17 \\
\hline a-Nph.5 ppm + Cuttings Wounding & 0 & 0 & 0 & 0 & 0 \\
\hline$\alpha-N p h .10$ ppm + Cuttings Wounding & 0 & 3.33 & 0 & 0 & 0.83 \\
\hline$\alpha-N p h .15$ ppm + Cuttings Wounding & 0 & 0 & 0 & 0 & 0 \\
\hline Mean & 4.99 & 0.41 & 0.83 & 0 & \\
\hline \multicolumn{6}{|l|}{ LSD at 0.05} \\
\hline Date & \multicolumn{5}{|c|}{0.0002} \\
\hline Treatments & \multicolumn{5}{|c|}{0.0003} \\
\hline Date $\times$ Treatments & \multicolumn{5}{|c|}{0.0005} \\
\hline
\end{tabular}

\section{2- Average number of roots per cutting:}

Results in Table 2 referred that the highest significant average number of roots per cutting were found at the treatments IBA (3500 ppm) + cuttings wounding and IBA (4500 ppm) + cuttings wounding respectively in comparison with the other treatments in both seasons, while the lowest significant were found at the treatment of wounding and beating alone. The other treatments showed that the hormone at different concentrations (IBA) + cuttings wounding was high significant average number of roots per cutting compared with the hormone at different concentrations $(\alpha-N p h)+$ cuttings wounding.

Concerning the effect of different date treatments, the results showed that middle November date gave the highest significant effect after dipping in IBA at $3500 \mathrm{ppm}+$ cuttings wounding in comparison with other dates in the two seasons. On the other hand, the lowest significant effect resulted from 
first January date. It can be concluded that the treatment IBA (3500 ppm) + cuttings wounding, at middle November is the best treatment for rooting as it averaged between 3.66 and 4 roots/cutting in both seasons, respectively.

Table 2: Effect of wounding alone or wounding with different concentrations from (IBA and $\alpha$-Naphthol) at different preparation of cuttings dates on the average number of rooted cuttings during 2006 and 2007 seasons

\begin{tabular}{|c|c|c|c|c|c|}
\hline \multicolumn{6}{|c|}{ Average number of rooted cuttings (roots/cutting) } \\
\hline \multicolumn{6}{|c|}{ Season 2006} \\
\hline Treatment & $\begin{array}{c}\text { Middle } \\
\text { Nov. }\end{array}$ & $\begin{array}{l}\text { First } \\
\text { Dec. }\end{array}$ & $\begin{array}{c}\text { Middle } \\
\text { Dec. }\end{array}$ & $\begin{array}{l}\text { First } \\
\text { Jan. }\end{array}$ & Mean \\
\hline Control & 2.00 & 0 & 0 & 0 & 0.50 \\
\hline Cuttings Wounding & 0 & 0 & 0 & 0 & 0 \\
\hline IBA (3500 ppm) + Cuttings Wounding & 3.66 & 0 & 2.00 & 0 & 1.41 \\
\hline IBA (4000 ppm) + Cuttings Wounding & 2.57 & 0 & 0 & 0 & 0.64 \\
\hline IBA (4500 ppm) + Cuttings Wounding & 3.00 & 0 & 2.00 & 0 & 1.25 \\
\hline a-Nph.5 ppm + Cuttings Wounding & 1.00 & 0 & 0 & 0 & 0.25 \\
\hline a-Nph.10 ppm + Cuttings Wounding & 0 & 1.00 & 0 & 0 & 0.25 \\
\hline a-Nph.15 ppm + Cuttings Wounding & 1.00 & 0 & 0 & 0 & 0.25 \\
\hline Mean & 1.67 & 0.13 & 0.50 & 0 & \\
\hline \multicolumn{6}{|l|}{ LSD at 0.05} \\
\hline Date & \multicolumn{5}{|c|}{0.0002} \\
\hline Treatments & \multicolumn{5}{|c|}{0.0003} \\
\hline Date $\times$ Treatments & \multicolumn{5}{|c|}{0.0005} \\
\hline \multicolumn{6}{|c|}{ Average number of rooted cuttings (roots/cutting) } \\
\hline \multicolumn{6}{|c|}{ Season 2007} \\
\hline Treatment & $\begin{array}{c}\text { Middle } \\
\text { Nov. }\end{array}$ & $\begin{array}{l}\text { First } \\
\text { Dec. }\end{array}$ & $\begin{array}{l}\text { Middle } \\
\text { Dec. }\end{array}$ & $\begin{array}{l}\text { First } \\
\text { Jan. }\end{array}$ & Mean \\
\hline Control & 0 & 0 & 0 & 0 & 0 \\
\hline Cuttings Wounding & 0 & 0 & 0 & 0 & 0 \\
\hline IBA (3500 ppm) + Cuttings Wounding & 4.00 & 0 & 2.00 & 0 & 1.50 \\
\hline IBA (4000 ppm) + Cuttings Wounding & 3.50 & 0 & 0 & 0 & 0.87 \\
\hline IBA (4500 ppm) + Cuttings Wounding & 3.500 & 0 & 2.00 & 0 & 1.37 \\
\hline a-Nph.5 ppm + Cuttings Wounding & 0 & 0 & 0 & 0 & 0 \\
\hline a-Nph.10 ppm + Cuttings Wounding & 0 & 2.66 & 0 & 0 & 0.66 \\
\hline a-Nph.15 ppm + Cuttings Wounding & 0 & 0 & 0 & 0 & 0 \\
\hline Mean & 1.37 & 0.33 & 0.50 & 0 & \\
\hline \multicolumn{6}{|l|}{ LSD at 0.05} \\
\hline Date & \multicolumn{5}{|c|}{0.0002} \\
\hline Treatments & \multicolumn{5}{|c|}{0.0003} \\
\hline Date $\times$ Treatments & \multicolumn{5}{|c|}{0.0005} \\
\hline
\end{tabular}

\section{3- Average length of roots per cutting:}

Results in Table 3 referred that the highest significant average length of roots per cutting were found at the treatments IBA $(3500 \mathrm{ppm})+$ cuttings wounding and IBA $(4500 \mathrm{ppm})$ + cuttings wounding respectively in comparison with the other treatments in both seasons, while the lowest significant were found at the treatment of wounding and beating alone. The other treatments showed that the hormone at different concentrations (IBA) + cuttings wounding was high significant average length of roots per cutting compared with the hormone at different concentrations $(\alpha-N p h)+$ cuttings wounding. 
Concerning the effect of different date treatments, the results showed that middle November date gave the highest significant effect after dipping in IBA (3500 ppm) + cuttings wounding in comparison with other dates in the two seasons. On the other hand, the lowest significant effect resulted from first January date. It can be concluded that the treatment IBA at $3500 \mathrm{ppm}+$ cuttings wounding, at middle November is the best treatment for rooting as it averaged between 3.16 and $4 \mathrm{~cm}$ in both seasons, respectively.

Table 3: Effect of wounding alone or wounding with different concentrations from (IBA and a-Naphthol) at different preparation of cuttings dates on the average root length (cm) of rooted cutting during 2006 and 2007 seasons

\begin{tabular}{|c|c|c|c|c|c|}
\hline \multicolumn{6}{|c|}{ Average root length $(\mathrm{cm})$} \\
\hline \multicolumn{6}{|c|}{ Season 2006} \\
\hline Treatment & $\begin{array}{c}\text { Middle } \\
\text { Nov. }\end{array}$ & $\begin{array}{l}\text { First } \\
\text { Dec. }\end{array}$ & $\begin{array}{c}\text { Middle } \\
\text { Dec. }\end{array}$ & $\begin{array}{l}\text { First } \\
\text { Jan. }\end{array}$ & Mean \\
\hline Control & 2.00 & 0 & 0 & 0 & 0.50 \\
\hline Cuttings Wounding & 0 & 0 & 0 & 0 & 0 \\
\hline IBA (3500 ppm) + Cuttings Wounding & 3.16 & 0 & 2.42 & 0 & 1.39 \\
\hline IBA (4000 ppm) + Cuttings Wounding & 2.00 & 0 & 0 & 0 & 0.50 \\
\hline IBA (4500 ppm) + Cuttings Wounding & 2.66 & 0 & 2.00 & 0 & 1.16 \\
\hline a-Nph.5 ppm + Cuttings Wounding & 1.00 & 0 & 0 & 0 & 0.25 \\
\hline a-Nph.10 ppm + Cuttings Wounding & 0 & 1.00 & 0 & 0 & 0.25 \\
\hline a-Nph.15 ppm + Cuttings Wounding & 1.00 & 0 & 0 & 0 & 0.25 \\
\hline Mean & 1.44 & 0.13 & 0.55 & 0 & \\
\hline \multicolumn{6}{|l|}{ LSD at 0.05} \\
\hline Date & \multicolumn{5}{|c|}{0.0002} \\
\hline Treatments & \multicolumn{5}{|c|}{0.0003} \\
\hline Date $\times$ Treatments & & & 0.0005 & & \\
\hline \multicolumn{6}{|c|}{ Average root length $(\mathrm{cm})$} \\
\hline \multicolumn{6}{|c|}{ Season 2007} \\
\hline Treatment & $\begin{array}{c}\text { Middle } \\
\text { Nov. }\end{array}$ & $\begin{array}{l}\text { First } \\
\text { Dec. }\end{array}$ & $\begin{array}{c}\text { Middle } \\
\text { Dec. }\end{array}$ & $\begin{array}{l}\text { First } \\
\text { Jan. }\end{array}$ & Mean \\
\hline Control & 0 & 0 & 0 & 0 & 0 \\
\hline Cuttings Wounding & 0 & 0 & 0 & 0 & 0 \\
\hline IBA (3500 ppm) + Cuttings Wounding & 4.00 & 0 & 2.00 & 0 & 1.50 \\
\hline IBA (4000 ppm) + Cuttings Wounding & 2.00 & 0 & 0 & 0 & 0.50 \\
\hline IBA (4500 ppm) + Cuttings Wounding & 2.25 & 0 & 2.00 & 0 & 1.06 \\
\hline a-Nph.5 ppm + Cuttings Wounding & 0 & 0 & 0 & 0 & 0 \\
\hline a-Nph.10 ppm + Cuttings Wounding & 0 & 2.16 & 0 & 0 & 0.56 \\
\hline a-Nph.15 ppm + Cuttings Wounding & 0 & 0 & 0 & 0 & 0 \\
\hline Mean & 1.03 & 0.27 & 0.50 & 0 & \\
\hline \multicolumn{6}{|l|}{ LSD at 0.05} \\
\hline Date & \multicolumn{5}{|c|}{0.0002} \\
\hline Treatments & \multicolumn{5}{|c|}{0.0003} \\
\hline Date $\times$ Treatments & \multicolumn{5}{|c|}{0.0005} \\
\hline
\end{tabular}

\section{2-Histological Studies:}

The microscopical study of the transverse sections Figures 1, 2, 3\& 4 showed that there are no clear differences between different dates of preparing cuttings in sclerenchyma cells volume and count. The microscopical study of the transverse sections Figures 1,2,3\& 4 of the four time reveal that failure of kalamata as (hard - to root) olive cv. may be correlated with density or 
continuity of the sclerenchyma ring, forming mechanical barrier to the emergence of newly formed rootlets sclerenchyma degradation or dissolving in kalamata cv. are also very slow Moreover thickness of the cortex cell layers possibly retarded the emergence of the newly formed roots same results were obtained by Emtithal et al. (1995).

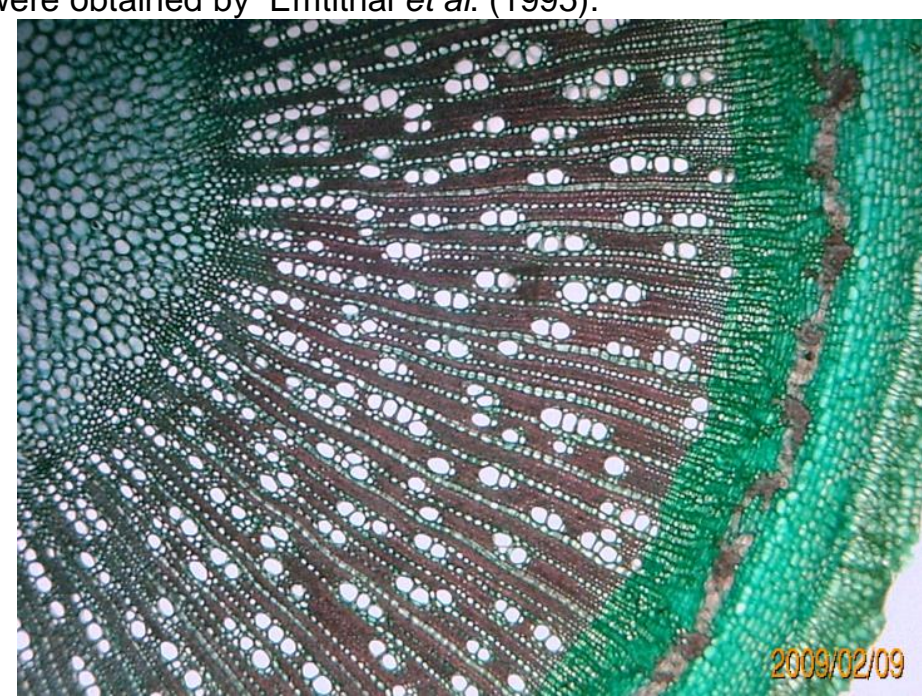

Fig. 1. Cross section in the bases of cuttings when were prepared in the middle November shows the cell density or continuity of the sclerenchyma ring.

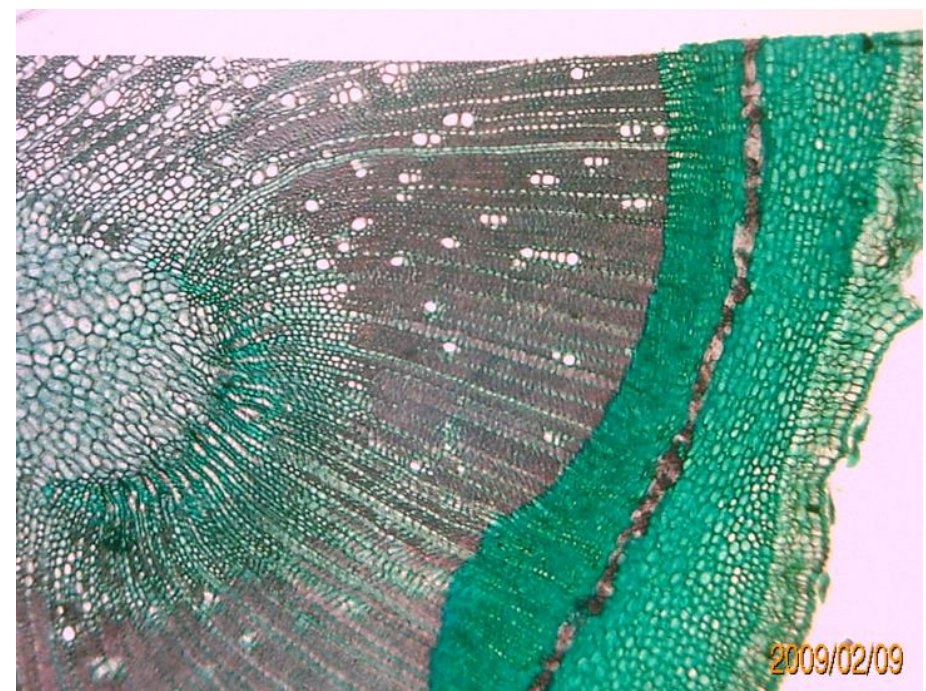

Fig. 2. Cross section in the bases of cuttings when were prepared in the First December shows the cell density or continuity of the sclerenchyma ring. 


\section{El- Ghayaty, S. H. et al.}

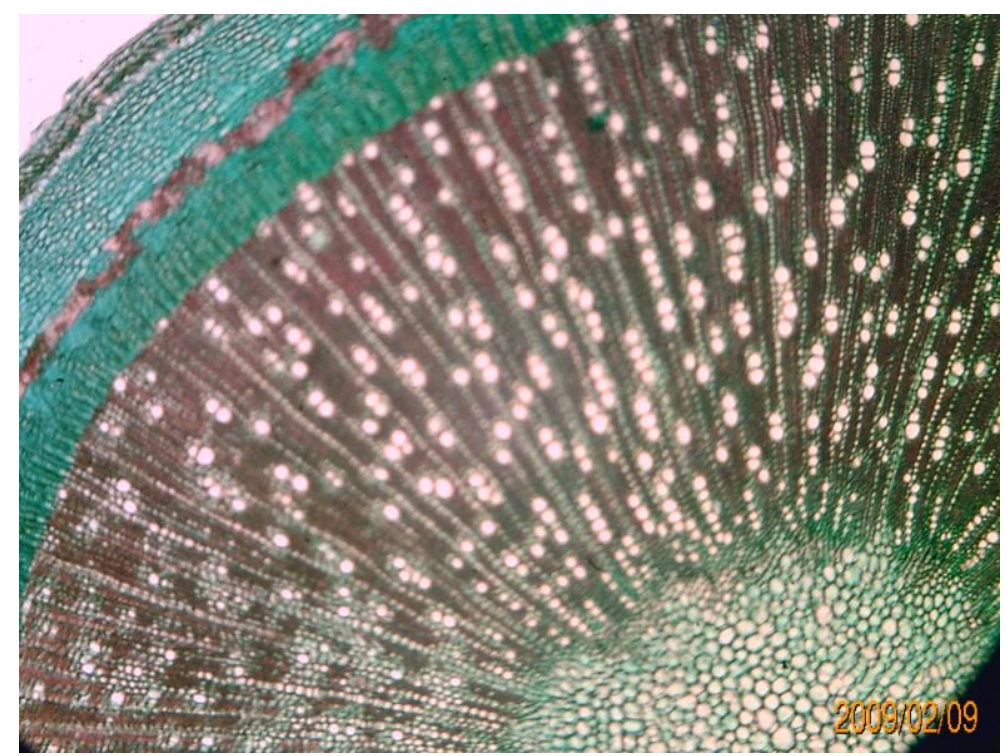

Fig. 3. Cross section in the bases of cuttings when were prepared in the middle December shows the cell density or continuity of the sclerenchyma ring.

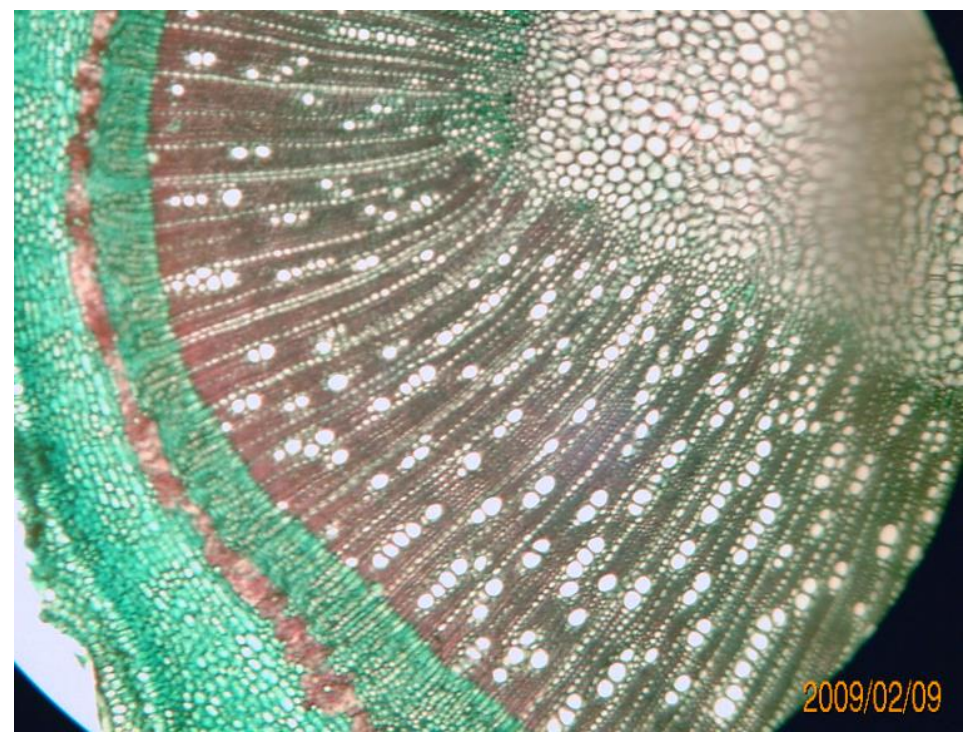

Fig. 4. Cross section in the bases of cuttings when were prepared in the First January shows the cell density or continuity of the sclerenchyma ring. 


\section{REFERENCES}

El Nabawy, S. M.; Bondak, A. and El-Din, I. S. (1983). Studies on some factors affecting rooting in olive leafy cuttings. Annals Agric. Sci., Fac. Agric. Ain-Shams Univ., Kalubia. Egypt, 28(3): 1649-1662.

El-Said, M, E.; El-Din, I. S. and Youssef, N. F. (1990). Studies on some factors affecting ability of leafy olive cuttings. Zagazig J. Agric. Res., 17(3B): 851-863.

El-Said, M. El-S. (1986). Comparative studies on some factors affecting rooting of olive cuttings. Ph. D. Thesis, Fac. of Agric., Cairo, University.

Emtithal H. El-Sayed; M. E. El-Said; A. H. El-Sherif and S. A. Sari El-Deen (1995). Studies on rooting ability and developmental stages of root formation in cuttings of easy-hard rooting olive cvs. Zagazig, J. Agric. Res., 22 (5): 1329-1349

Fouad, M. M.; Fayek, M. A.; Salim, H. H. and El-Sayed, M. E. (1989). Rooting of olive cultivars under mist. "Olea" International Symposium on Olive Growing, September 26-29. Page14. Cordoba (Spain).

Johansen, D.A. (1940). Plant Microtechnique $5^{\text {th }}$ ed. McGraw-Hill, Book Company. Inc., New York, USA. p.523.

Sachs, R.M.; Loreti, F. and De Bie, J. (1964). Plant rooting studies indicate sclerenchyma tissue is not a restricting factor. Calif. Agric., 18(9): 4. (C.F. Hort. Abst. 35. 359).

Salama, M.A; Zahran, M.A. and Hassan, M.M. (1987). Comparing the rooting ability of some olive cu1tivars propagated by leafy cuttings under mist. Annals Agric. Sci., Fac. Agri. Ain Shams Univ. Cairo, Egypt, 32(1): 577-590.

Steel, G.D. and J.H. Horrie (1960). Principles and Procedures of Statistics. McGraw - Hill Book Co. Inc., New York.

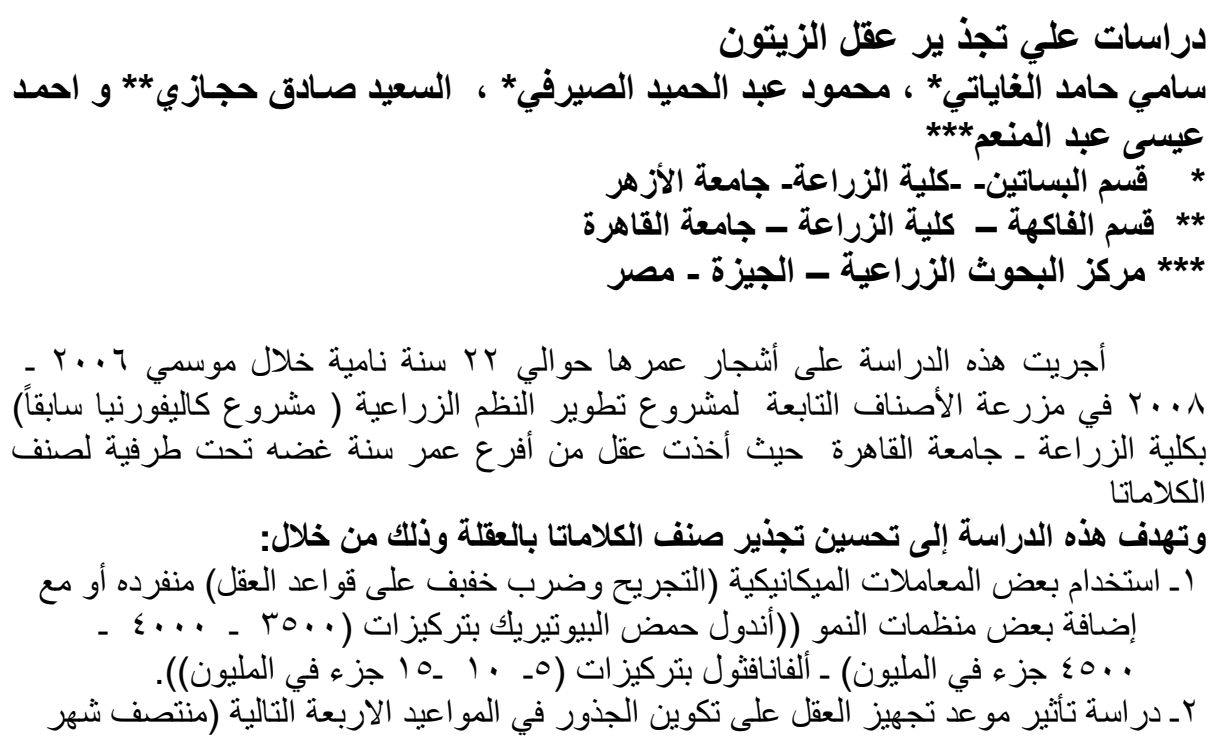




\section{El- Ghayaty, S. H. et al.}

نوفمبر ـ أول شهر ديسمبر ـ منتصف شهر ديسمبر - أول شهر يناير).

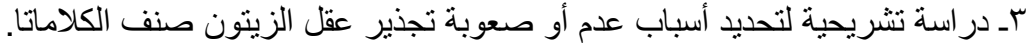

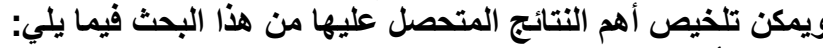

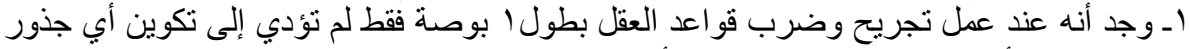

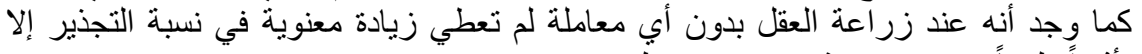

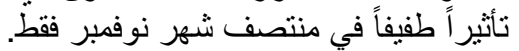

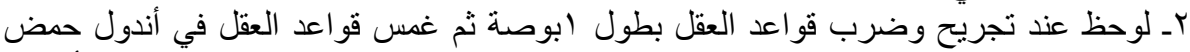

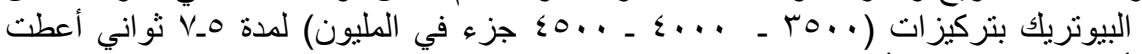

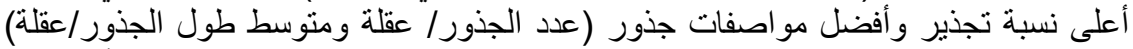

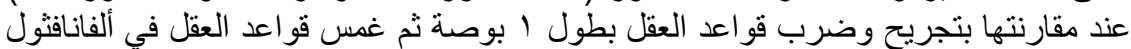

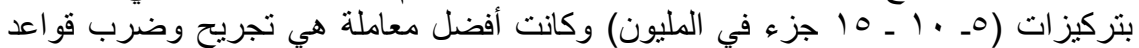

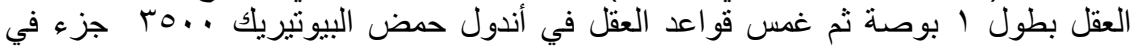

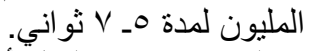

rـ كان لموعد تجهيز العقل أنثر واضح على مقدرنها على تكوين الجذور حيث اتضح أنح أن تجهيز

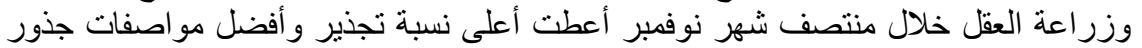

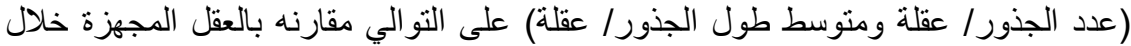

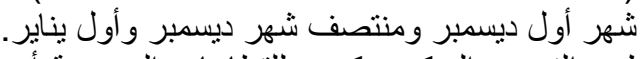

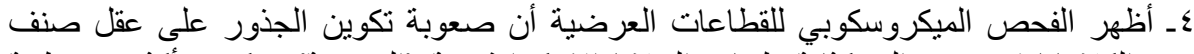

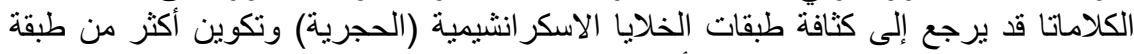

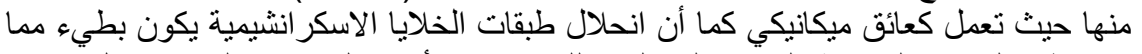

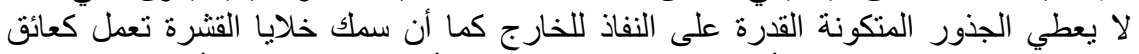

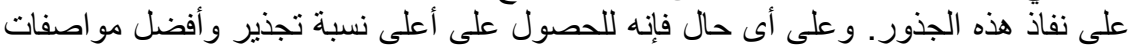

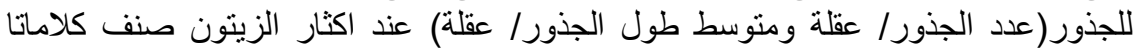

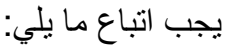

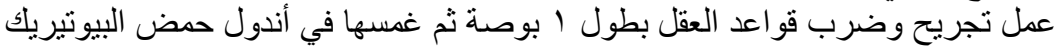

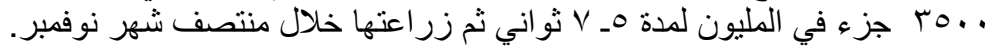

كلية الزراعة - جامعة المنصورة قام بتحكيم البحث كلية الزراعة - جامعة القاهرة 